\title{
Regional Economic Favoritism and Redistributive Politics as a Public Good: The Case of Tigray Region in Northern Ethiopia
}

\author{
Aynalem Adugna ${ }^{1}$ \\ ${ }^{1}$ Department of Geography, Planning, and Environment Sonoma State University, USA \\ Correspondence: Aynalem Adugna, Department of Geography, Planning, and Environment Sonoma State \\ University, California, California Department of Social Services, USA. E-mail: \\ AynalemAdugna@aol.com/Aynalem.Adugna@dss.ca.gov
}

Received: January 1, 2019

Accepted: January 16, $2019 \quad$ Online Published: February 26, 2019

doi:10.5539/jgg.v11n1p1

URL: http://dx.doi.org/10.5539/jgg.v11n1p1

\begin{abstract}
The study investigated whether or not misdirection of public resources to a favored region brings material improvements in the lives of the population that is alleged to be receiving the resources. In this study, the region in question is Tigray province in northern Ethiopia. Economic data from the 2016 Demographic and Health Survey (DHS) are examined with a focus on Tigray Region. The neighboring Amhara Region is used as control. Sample data on 1734 households from Tigray and 1902 households from Amhara Region were analyzed without weighting using the statistical software SAS 9.4 and the Geographic Information System software ArcGIS 10.4.1. We found evidence of a statistically significant advantage for Tigray Region in ownership of four modern amenities - radio, mobile phones, refrigerator, and access to electricity by individual households $(p<0.001)$. However, we did not find evidence of greater wealth in Tigray for the general population when the analysis was rerun based on DHS' wealth index. On the contrary, the data for sampling clusters in Tigray appeared to show the region as being poorer than Amhara when viewed through the lens of DHS' wealth index which is a more comprehensive measure of economic wellbeing than owning a radio or possessing a mobile phone. A one-tailed Wilcoxon Man-Whitney U statistic of DHS' wealth index for Tigray and Amhara Regions showed a statistically significant difference ( $<<$ 0.001) with a higher mean score for Amhara Region (1870.3) than for Tigray Region (1761.6) suggesting a better economic standing for the population of Amhara Region than Tigray Region. We also found Amhara Region to be more egalitarian and Tigray Region less so on the scale of livelihoods captured by DHS' economic indicators. Evidence for this comes from a Geographic Information System (GIS) Kernel Density analysis of DHS' wealth index which showed what appear to be significant geographic concentrations of both poverty and wealth in Tigray Region.
\end{abstract}

Keywords: Ethiopia, redistributive politics, regional favoritism, Tigray, DHS wealth index

\section{Introduction}

\subsection{The Problem}

A number of outcomes are linked to actions by politicians directing or redirecting disproportionate shares of public resources to a favored geography, often their own region of birth. These actions include the following: 1) targeted benefits are provided to individuals or groups in the favored region while the general population sees no gain (Asher and Novosad, 2017) 2) the entire public benefits but it does so at the expense of the population in nonfavored regions (Manh Vu and Yamada, 2017), 3) no one benefits as ill-intentioned program implementations result in significant waste which leads to mass anger accompanied by violence (Ilorah, 2009), 4) international aid dollars and national resources in the form of liquid assets are redirected by those in positions of power away from their region of birth for safe keeping in international banks, or for investments abroad. It is often not clear which of these four outcomes is the most likely occurrence. For Kramon and Posner (2013) the answer depends in part on the objectives of the study in regional favoritism and redistributive politics - cash transfers, roads, educational spending, electrification, or targeted grants? This study seeks to find out if any of the above four scenarios apply in Ethiopia, and to provide answers that contribute to the literature on the subject of regional favoritism and redistributive politics by analyzing economic indicators found in the country's 2016 Demographic and Health Survey. It does so by looking for evidence of the household-level impacts of disproportionate resource allocations that have allegedly benefitted the population Tigray Region in northern Ethiopia (Figure 1). 


\subsection{Redistributive Politics as a Public Good: Review of the Literature}

Regional favoritism and distributive politics are not new in Ethiopia but are said to have intensified in the 1990s following the ascendance of the Tigray Peoples Liberation Front (TPLF) which took control of both the regional and national governments in 1991. The claim that disproportionate allocation of public goods and services has been benefitting Tigray Region is not surprising given the government's declared policies of rehabilitating areas ravaged by war - a euphemism for Tigray Region itself - and its reluctance to fully endorse the private sector which it viewed as rent-seeking or untrustworthy (Vaughan and Gebremichael, 2011). It chose, instead, the promotion of government-controlled mega projects, or use of fronts such as the Endowment Fund for the Rehabilitation of Tigray (EFFORT) as vehicles for implementation of centrally planned economic programs (Vaughan and Gebremichael, 2011). EFFORT has become a national umbrella company for businesses engaged in industry, construction, agribusiness, banking, insurance, mining, import and export, as well as media and communications. It has now grown from its initial capital of US\$100 million to a whopping US\$3 billion in paid capital (Uliah, 2017).

Luca and Rodríguez-Pose (2015) have challenged much of the distributive politics literature which they believed, have overly emphasized the role of pork-barrel in public policy-making. In this study, we are not equating the alleged misdirection of public resources to a pork-barrel - a metaphor for appropriations intended to bring funds to a representative's district. We do not consider it pork-barrel because politicians from Tigray have had no fear of losing power in an election as all contests hitherto undertaken in the region and elsewhere in Ethiopia had predetermined outcomes. To the extent that election results did not match the expectations of the party in power, force was used to "right the wrongs" as was the case in the 2005 election (Carter Center, 2009).

Instead, we are researching the possibility that regional economic favoritism, a form of corruption in which leaders funnel public goods and international aid moneys both to themselves and to their region of birth (Dreher, et. al. 2010; Rainer, 2009; and UNDP, 2017) may have taken place in Ethiopia. In a recent study, satellite data on nighttime light intensity was matched up with information about the birthplaces of political leaders in 38,427 subnational geographies from 126 countries. The results showed subnational regions to have more intense nighttime lighting if they are the birth region of current leaders, especially in countries with weak political institutions and poorly educated citizenry (Hodler and Raschky, 2014). Asher and Novosad's (2017) study also showed regional favoritism as leading to higher private sector employment, better share prices, and increased output as measured by night lights. However, the overall socio-political and economic benefits for receiving regions and the negative consequences for non-receiving regions have not been studied extensively. As a result, whether or not redistributive politics broadly benefits the population of receiving regions as a whole or just a select few individuals, has not been verified. Is redistributive politics a public good? In other words, do the targeted regions and populations experience substantial improvements in their livelihoods?

This study attempts to fill this knowledge gap by examining the possible household-level impacts of alleged regional economic favoritism of the last two and half decades, thought to have conferred disproportionate economic benefits upon the northern Ethiopian province of Tigray (McCracken, 2004; Aalen, 2016). It does so by using the neighboring Amhara Region as control and in line with conventional definitions which view redistributive politics as resource allocation favoring one region at the expense of all others (Hazelkorn and Gibson, 2017; Golden and Min, 2013). The focus of Hazelkorn and Gibson's (2017) review was also the unfair allocation of public goods and services to identifiable localities or groups. We will rely on the summary findings of 150 studies on the subject of public good by Golden and Min (2013) who saw regional favoritism and redistributive politics as the conferring of geographically concentrated benefits while diffusing costs across all regions. Many of the studies Golden and Min (2013) reviewed saw distributive politics as involving misallocation of tax revenues and transfers of goods and services. Does Matthew J. McCracken's (2004) observation of significant economic advantages for Tigray region fit this description? We say that the truth is much more nuanced and very much depends on the scale of analysis; person-level versus societal-level. Determination of the scope is further complicated by the fallacy of viewing as indicators of economic progress structures often patronized by the general public including high-rise buildings, shopping malls, entertainment venues, stadiums etc. or ownership of the trappings of modernity such as mobile phones, radio, refrigerators etc. Given the largely agrarian existence in Amhara and Tigray Regions and in the rest of Ethiopia, we argue that traditional measures of wellbeing such as land ownership and land productivity as well as animal raising and access to markets and credits should be weighed more heavily. We therefore, believe that a better measure of economic wellbeing is the country-specific wealth index developed by DHS for all of its surveys (Rutstein and Johnson, 2004). DHS' wealth indices use statistical methods, factor analysis in particular, to create person- and household-level scores based on county-specific measures such as type of flooring, water supply, ownership of motorized vehicles, sanitation facilities, number of 
persons per room, ownership of agricultural land, and the presence of a domestic servants (Rutstein and Johnson, 2004).

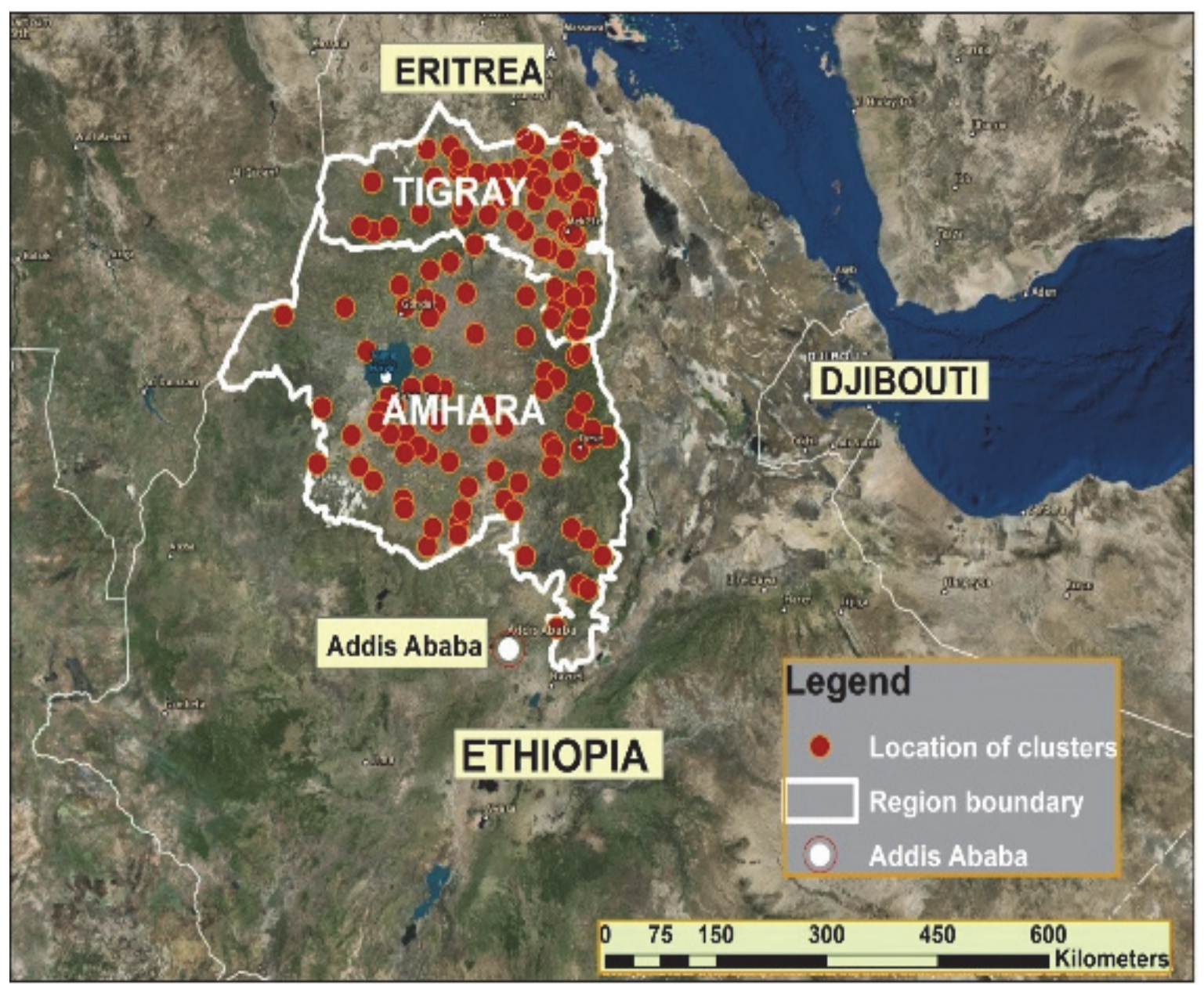

Figure 1. The location of Amhara and Tigray and the 2016 Demographic and Health Survey Sampling Clusters

\subsection{Redistributive Politics in Ethiopia}

Writing in an international law journal, McCracken (2004) poured scorn on the ruling Ethiopian People's Revolutionary Democratic Front (EPRDF) citing its subservient complicity in the diversion of public resources to Tigray Region, the home province of its founding member TPLF. McCracken's reporting included the statement that Tigray Region was territorially limited and economically underdeveloped prior to 1991 when TPLF assumed its dominant role in EPRDF and in Ethiopia's political and economic life. The diversion of resources is said to have been very direct as disproportionally large shares of goods and services were either shipped straight to the region, or were indirectly funneled through EFFORT. In a related report, Reid (2003) maintained that Tigray's territorial limitation was resolved through annexation of fertile lands in neighboring Amhara Region while Eritrea - a neighbor to the north - which won its independence from Ethiopia in 1993 also found itself engaged in a bitter border war with TPLF's Ethiopia. McCracken (2004) sums up the end result as a significant gain for Tigray while the rest of the county stagnated or lagged behind. Is this true, and if yes, did the population of Tigray derive measurable material gains above and beyond economic advances registered in other parts of the country?

The answer could depend partly on what one chooses to measure. For instance, results of four Demographic and Health Surveys conducted in Ethiopia (Figure 2) show greater improvements over time for Tigray Region in access to health care and health outcomes than for Amhara Region (Central Statistical Authority and ORC Macro 2001, 2006, 2012, 2017). Figure 2 shows far bigger reductions in infant and child mortality, higher prevalence of modern contraceptives, higher literacy among women, and lower incidences of female genital cutting (circumcision) in Tigray Region than in Amhara. However, it also shows greater prevalence of childhood stunting and higher percentages of underweight children in Tigray Region than in Amhara. The observation of high levels of childhood stunting in Tigray is consistent with other data showing higher poverty in this region, with 58 percent of the 
Tigray's population said to be earning less than a dollar per day (WFP-Ethiopia, 2009; Argaw, 2017). A report by Tigray Regions Housing Development Agency (2017) estimated the proportion of Mekele's (Tigray's capital) inhabitants who live in slums at more than half. The rise of slums in Mekele City where we also have privately owned four- and five-star luxury hotels including Axum Hotel, is said to be the result of unmanaged urbanization the socio- economic ills of which remain unmanaged (World Bank, 2015). Adding to the debate of whether or not redistributive politics benefitted the people of Tigray, is the view expressed in parliament in July of 2018 by Ethiopia's new prime minister Abiy Ahmed who is not a Tigrean. Speaking in the official Amharic language, the prime minister said "ye Tigray hizb minim yelewum", which translates as "the people of Tigray have nothing".

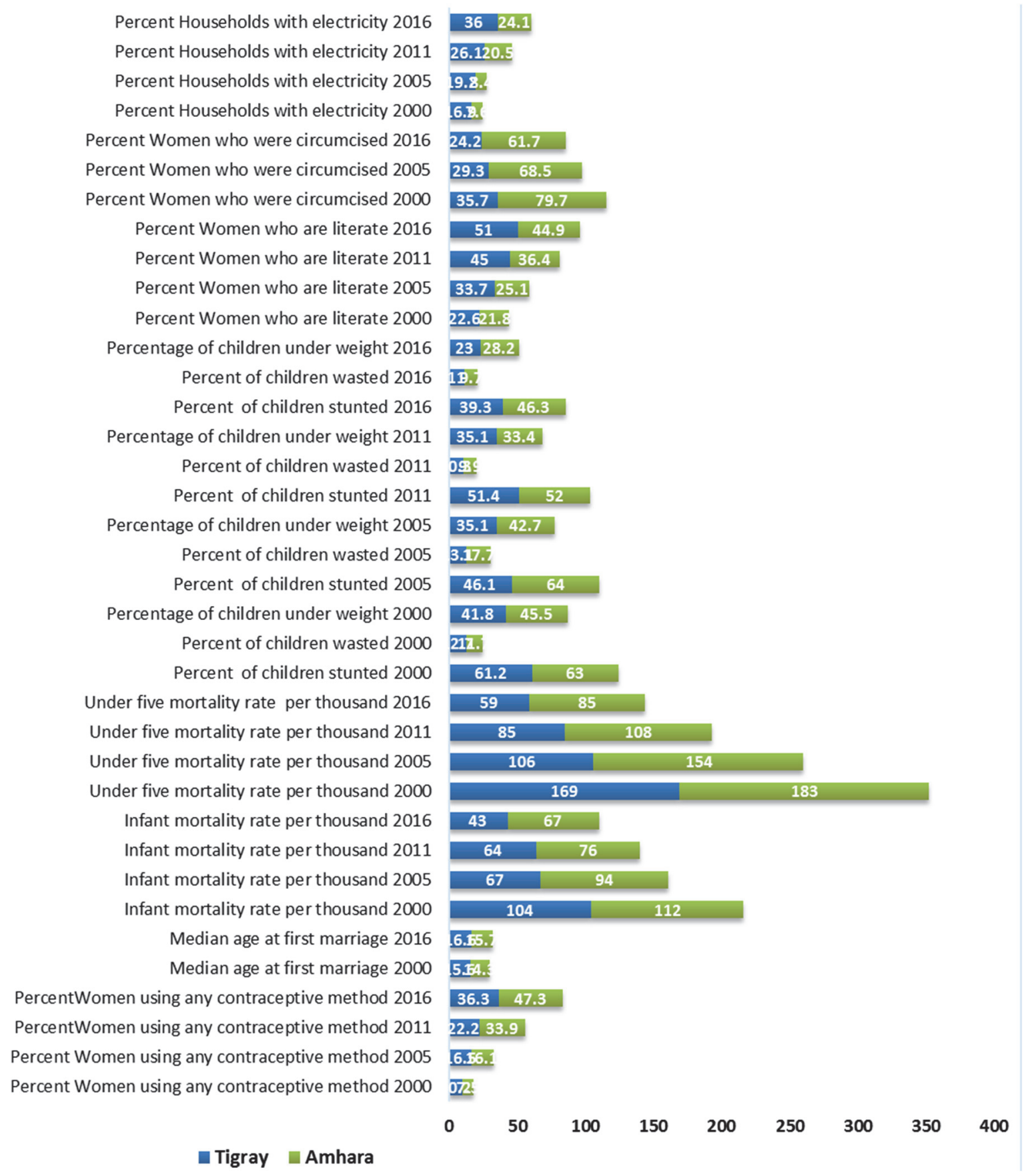

Figure 1. Demographic and Health Indicators for Amhara and Tigray Regions

Data sources: Central Statistical Authority and ORC Macro (2001, 2006, 2012, 2017)

1.4 Tigray Region, Redistributive Politics, and the Federal System 
Tigray's TPLF assumed both national and regional power in 1991 after forming a coalition known as EPRDF with three other ethnic-based fronts thought to represent much of the rest of the country (Yilmaz and Venugopal, 2008). While its base was solidly the Tigrean towns and countryside, its leadership was composed primarily of idealistic college dropouts sympathetic to Marxist-Leninist views of socioeconomic change (Tadesse, 2003). TPLF's cofounder Meles Zenawi became the leader of the governing coalition and ruled the county until his death in 2012. The EPRDF coalition remains the dominant party in the country with a 100 percent control of parliament albeit with a diminished role for TPLF which lost much of its luster and political power after 27 years of supremacy and total dominance following the April 2018 rise to power of a new prime minister.

The early 1990s ushered in a new era of federalism composed of nine ethnic-based regions with an option for any of the nine to break away by invoking Article 39 of the Ethiopian constitution (Abdullahi, 1998). This, some say, was a ploy to break away Tigray Region from the rest of the country after it had become sufficiently richer and stronger, thanks in part to disproportionate resource transfers and territorial expansion. It was widely reported that significant resource transfer was taking place under this federal arrangement with the pretext of healing the economy and society of a war-ravaged region - a indirect reference to Tigray Region itself. Did the federal structure and alleged resource transfers bring economic empowerment to ordinary Tigreans so much so that they could contemplate a successful secession from the rest of Ethiopia? A far more basic question is whether the population of Tigray attained a higher economic status than other regions in the federal system. This paper will examine whether or not the alleged misdirection of public resources and international aid dollars to Tigray created a public good for ordinary Tigreans. In other words, did TPLF manage to elevate the economic standing of ordinary Tigreans before losing power in a recent shakeup? The study will provide answers based on analysis of two groups of variables: 1) ownership of modern amenities, namely radios, mobile phones, refrigerators, and access to electricity 2) DHS' wealth index which includes traditional indicator variables such as access to land and housing, and ownership of farm animals which, collectively, are a better measure of livelihoods among agrarian populations such as those in Tigray and Amhara.

\section{Objectives}

Our main objective is to answer the question of whether or not the population of Tigray derived material gain from alleged regional economic favoritism and redistributive politics which is thought to have conferred upon it benefits that were geographically concentrated in this region while diffusing costs across all other regions. Our null hypothesis is that it did not. We test this hypothesis by comparing Tigray Region with the neighboring Amhara Region where the socio-economic circumstances of the early 1990s when TPLF/EPRDF came to power were more or less identical. Amhara Region had a population of 13 million at the time (FDRE, 1995), roughly four times the size of Tigray's population which was about three million (FDRE, 1995). Tigray's current population is estimated to be 5.8 million and Amhara Region's population is thought to be around 23.4 million (Aynalem, 2017).

\section{Methodology}

Data on economic indicators collected during the 2016 Ethiopian Demographic and Health Survey (DHS) are used. This is the fourth such survey in the country, and part of a global data collection effort involving over 90 countries. Ethiopia's DHS was designed to provide estimates at the national level and for each of the 9 regions and 2 city administrations using sample data that was collected in both urban and rural areas. The sampling frame was the 2007 Ethiopia Population and Housing Census. The first stage of the survey involved 202 urban and 443 rural clusters that were randomly selected. The second stage involved the random selection of 28 households per cluster. A total of 18,008 households were chosen for the 2016 survey, of which 17,067 were occupied. The selected households were visited and members were interviewed (Central Statistical Authority and ORC Macro, 2016).

\subsection{Data Source}

The raw data was downloaded from the DHS website in SAS file format together with a geographical file containing the latitude/longitude locations of 60 sampling clusters in Tigray and 74 clusters in Amhara. We used the household-level data known as the Household Recode file (HR) file. Data on a total of 1,734 households in Tigray and 1,902 households in Amhara was extracted for this study. We did not use the Individual Recode (IR) file consisting of only women interviewees or the men's recode (MR) file. Neither did we use the Children's recode (KR) file of persons under 5 years of age whose mothers were interviewed. We chose the HR file because our unit of analysis is the household.

\subsection{Study Variables}

We selected a total of five variables, all relating to the economic standing of households. We did not include social 
or health variables as the focus of this study is purely the economic status of households in Amhara and Tigray regions, and whether or not there is a statistically significant difference in that status. The variables we have chosen are 1) ownership of a mobile telephone, radio, refrigerator, and whether or not the home had electricity, and 2) DHS' wealth index for each household. We consider DHS' wealth index to be the better of the two categories of economic variables as it measures the overall economic wellbeing of the household, and not just the trappings of modernity such as ownership of a refrigerator. This means that we are placing a bigger emphasis on DHS' wealth Index as we try to answer the question of whether or not the economic wellbeing of the population of Tigray is statistically significantly better than that of Amhara Region at population levels.

\subsection{Research design}

Four of the five chosen variables have three categorical values each - no (0), yes (1), and not stated (9). The fifth variable - DHS' wealth index - has five categories, also known as quintiles, ranging from 1 (poorest) to 5 (richest). There were no missing cases. It was determined that the best statistic to use in this situation is the non-parametric Wilcoxon-Mann-Whitney test by running the PROC NPAR1WAY procedure in SAS statistical program. The NPAR1WAY procedure produces the $U$ statistic and exact p-values for the two-samples while testing for location and scale differences (SAS Institute Inc, 2008). The null hypothesis considers the values to have the same distribution in both Amhara and Tigray, and therefore identical total scores. The alternative hypothesis considers the total scores to be unequal. For each level of the class variable, which in this case is "region", PROC NPAR1WAY provides: 1) sums of the Wilcoxon scores, 2) the expected sum under the null hypothesis of no difference among class levels, and 3) the mean scores. If an observation has a missing value for a response variable, PROC NPAR1WAY excludes that observation from the analysis.

The test statistic for the Mann Whitney $U$ Test is denoted $\mathbf{U}$, and is the smaller of $U_{1}$ and $U_{2}$ :

$$
\begin{aligned}
& \mathrm{U}_{1}=\mathrm{n}_{1} \mathrm{n}_{2}+\frac{n 1(n 1+1)}{2}-\mathrm{R}_{1} \\
& \mathrm{U}_{1}=\mathrm{n}_{1} \mathrm{n}_{2}+\frac{n 2(n 2+1)}{2}-\mathrm{R}_{2}
\end{aligned}
$$

Where $\mathrm{R}_{1}=$ sum of the ranks for group 1 ; and $\mathrm{R}_{2}=$ sum of the ranks for group 2 .

In Wilcoxon Man-Whitney U statistic, the relative distribution of values in each sample matters more than how large or small the values are. In other words, whether or not an observation in one sample is greater or less than an observation in another sample is important; not by how much it is greater or smaller. This means that the Wilcoxon Man-Whitney U statistic is a non-paired, non-parametric test based only on statistical comparison of the means. Conditions for its application included randomness of the sample and the two samples being independent of one another (SAS Institute Inc, 2008). We believe that the DHS sample data for Amhara and Tigray Regions fulfils all of these requirements. The null hypothesis is that the two samples have the same distribution and have identical means. The alternative hypothesis is that the two samples have dissimilar distributions and unequal means.

We also used ArcMap 10.4.1 - a geographic information system (GIS) software - to conduct locational analysis of the chosen clusters. In particular, we used Kernel Density Estimation (KDE) which is a useful statistical tool. $\mathrm{KDE}$ is a technique that lets one create a smooth curve given a set of spatial data that is placed on a map through a geocoding process. Geocoding converts locational data into geographic coordinates (Daniel, 2008). The concept of weighting the distances of observations in space, in this case, the distance between sampling clusters in Tigray and Amhara Regions from a particular point, $x$, can be expressed mathematically as follows:

$$
f(x)=\sum_{\text {observations }}^{\infty} K\left(\frac{\mathrm{x}-\text { observations }}{\text { Bandwidth }}\right)
$$

Where the variable $K$ represents the kernel function.

$\mathrm{KDE}$ is a non-parametric method of estimating the probability density function (PDF) of a continuous random variable (Eric Cai, 2013) as it does not assume normalcy of the underlying distribution. At every datum, a kernel function is created with the datum at its center. A datum is a set of reference points on the earth's surface against which position measurements are made. A datum provides a frame of reference for measuring locations on the surface of the earth and defines the origin and orientation of latitude and longitude lines used around the world (Timár and Molnár, 2013).

\section{Results}


Our analysis of the ownership of mobile phones, radio, refrigerator, and access to electricity produced the results shown in Tables 1 and 2. The DHS' wealth index shown at the bottom of Table 2 uses quintiles based on material possessions of households (Rutstein and Johnson, 2004) with each household member's assets taken into account. Results of the analysis of the wealth index are shown at the bottom of Table 2 .

Table 1. Ownership of Refrigerator, Radio, Mobile Phone, and Access to Electricity in Amhara and Tigray Regions: Percentage of the Sample Population Providing a "Yes" or "No" Answer.

\begin{tabular}{|c|c|c|c|c|c|c|c|c|}
\hline & \multicolumn{2}{|c|}{ Owns a refrigerator } & \multicolumn{2}{|c|}{ Owns Radio } & \multicolumn{2}{|c|}{ Mobile Phone } & \multicolumn{2}{|c|}{ Has Electricity } \\
\hline & Tigray & Amhara & Tigray & Amhara & Tigray & Amhara & Tigray & Amhara \\
\hline No & 1,612 & 1,871 & 1,235 & 1,523 & 673 & 989 & 1,138 & 1,549 \\
\hline$\%$ No & 93.0 & 98.4 & 71.2 & 80.1 & 38.8 & 52.0 & 64.0 & 75.9 \\
\hline Yes & 122 & 31 & 499 & 379 & 1,061 & 913 & 596 & 353 \\
\hline$\%$ Yes & 7.0 & 1.6 & 28.8 & 19.9 & 61.2 & 48.0 & 36.0 & 24.1 \\
\hline
\end{tabular}

Table 2. Wilcoxon-Mann-Whitney Non-parametric Test Results for Amhara and Tigray Regions

\begin{tabular}{|c|c|c|c|c|c|c|}
\hline & Region & $\begin{array}{l}\text { Sum of } \\
\text { Scores }\end{array}$ & $\begin{array}{l}\text { Expected } \\
\text { Under H0 }\end{array}$ & $\begin{array}{l}\text { Mean } \\
\text { Score }\end{array}$ & Z-score & \begin{tabular}{l}
\multicolumn{1}{c}{ One } \\
sided $\operatorname{Pr}>$ \\
$\mathrm{Z}$
\end{tabular} \\
\hline \multirow[t]{2}{*}{ Refrigerator } & Amhara & 3369642.0 & 3458787.0 & 1771.6 & & \\
\hline & Tigray & 3242424.0 & 3153279.0 & 1869.9 & 8.10 & $<.0001$ \\
\hline \multirow[t]{2}{*}{ Radio } & Amhara & 3312831.0 & 3458787.0 & 1741.7 & & \\
\hline & Tigray & 3299235.0 & 3153279.0 & 1902.6 & 6.22 & $<.0001$ \\
\hline Mobile & Amhara & 3241347.0 & 3458787.0 & 1704.1 & & \\
\hline Phone & Tigray & 3370719.0 & 3153279.0 & 1943.8 & 7.97 & $<.0001$ \\
\hline \multirow[t]{2}{*}{ Electricity } & Amhara & 3198042.0 & 3458787.0 & 1681.4 & & \\
\hline & Tigray & 3414024.0 & 3153279.0 & 1968.8 & 10.84 & $<.0001$ \\
\hline \multirow[t]{2}{*}{ Wealth Index } & Amhara & 3557429.5 & 3458787.0 & 1870.3 & & \\
\hline & Tigray & 3054636.5 & 3153279.0 & 1761.6 & -3.19 & $<.0001$ \\
\hline
\end{tabular}

At first glance, Tables 1 and 2 appear to confirm the claim that Tigray Region has indeed benefitted from alleged redistributive politics and economic favoritism. The percentages of the populations owning mobile phones, radio, and refrigerator, as well as the share of those with access to electricity are consistently higher in Tigray than in Amhara. The one-tailed Wilcoxon Man-Whitney U statistics are significant $(p<0.001)$ for these four variables. However, we should be mindful of the very small numbers and percentages of persons responding "yes" to owning these amenities both in Amhara and Tigray. For instance, even though Tigray has higher refrigerator ownership, the percentage is only single digit.

Conversely, our analysis of DHS' wealth index found no evidence of a stronger economic base in Tigray at population levels. Tigray actually comes off as a poorer Region than Amhara when population-level economic indicators are taken into account as is the case with DHS' wealth index. A one-tailed Wilcoxon Man-Whitney U statistic showed statistically significant $(p<0.001)$ difference in wealth index with a higher mean score for Amhara Region (1870.3) than for Tigray Region (1761.6) (Table 2). Based on this result, it appears that the population of Tigray is, in fact, poorer (not richer) than the population of Amhara Region. However, as this is a population-level finding, it by no means is a pointer to greater accumulation of wealth in the hands of affluent Amharas than Tigreans. As is explained in the discussion section below, the reverse is true when it comes to individual-level wealth held by affluent Amharas and Tigreans. 


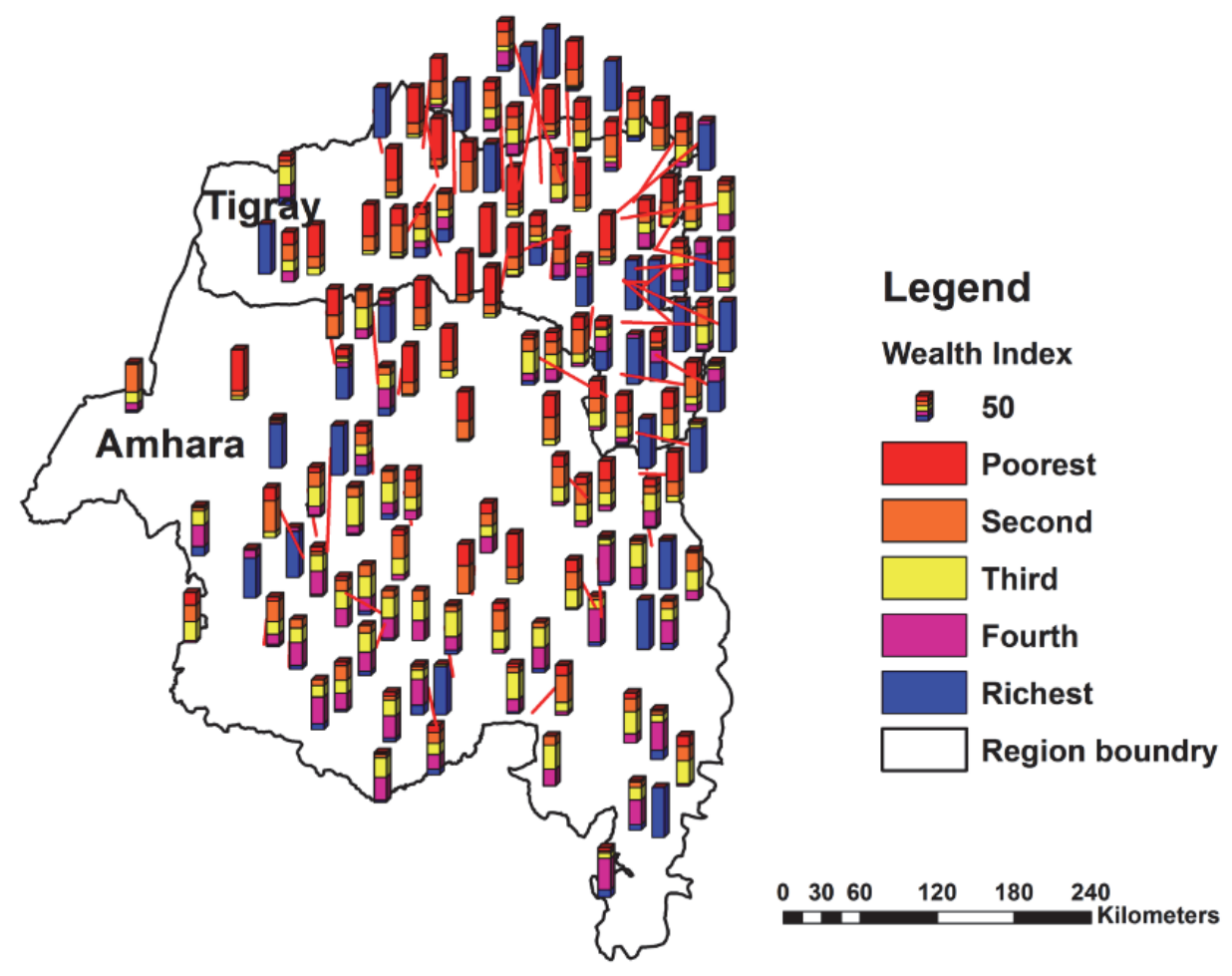

Figure 3a. Proportion of Sampling Clusters in Amhara and Tigray by Wealth Quintiles

Data source: Central Statistical Office and ORC MACRO (2017)
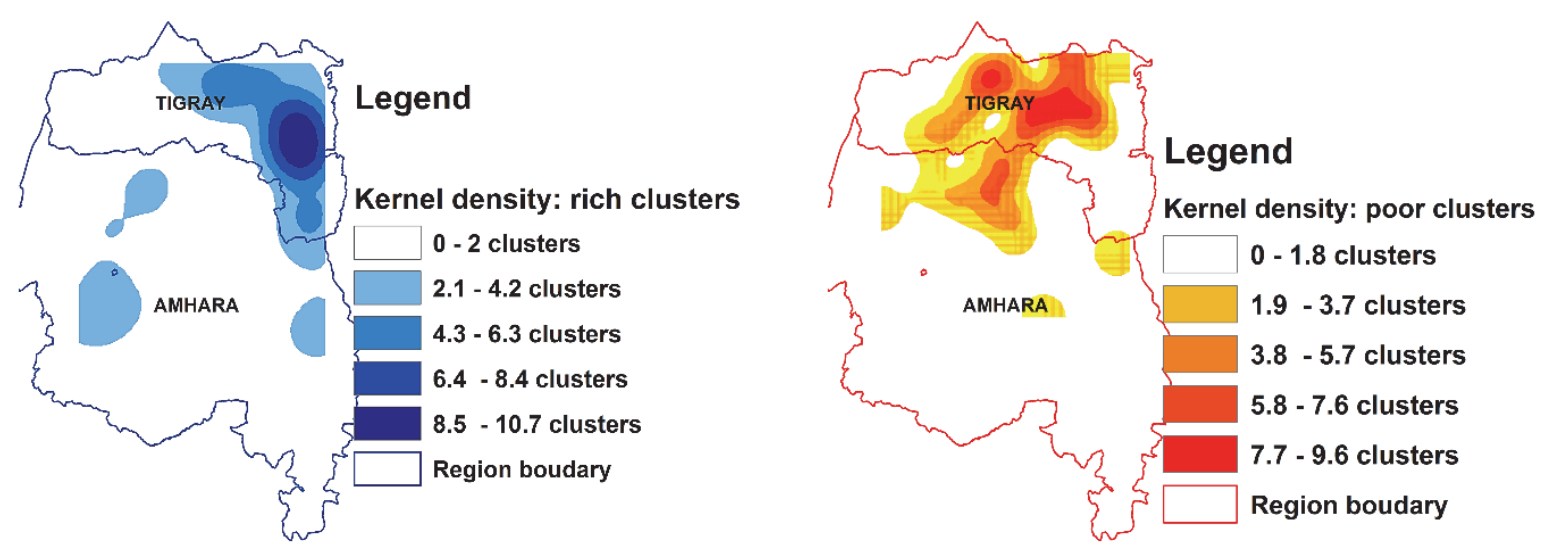

Figure $3 \mathrm{~b}$ and $3 \mathrm{c}$. Kernel Density of Clusters with $>50 \%$ Rich Households (blue) and $>50 \%$ Poor Households (yellow/orange/red)

Data source: Central Statistical Office and ORC MACRO (2017)

The stacked bar graphs in Figure 3a represent percentages of households in sampling clusters in the five DHS wealth quintiles ranging from poorest (red) to richest (blue). In Figure $3 \mathrm{~b}$ and $3 \mathrm{c}$, we only mapped clusters where the majority (greater than 50 percent) of households were in the first quintile (poorest), or clusters where the majority of households (greater than 50 percent) were in the fifth quintile (richest). There were 14 sampling clusters (23\%) fitting the majority poor criteria in Tigray and 9 clusters (12\%) in Amhara Region. There were 17 sampling clusters (28\%) fitting the majority rich criteria in Tigray Region, and 11 clusters $(15 \%)$ in Amhara Region. We used these clusters to create a continuous density surface (Kernel Density) of rich clusters (blue raster), and a continuous density surface of poor clusters (yellow/orange/red raster) in the two regions combined. The clearest outcome of this exercise is the finding of an apparent regional difference in the level of income inequality which appears to be greater in Tigray region (Figures 3b and 3c) than in Amhara Region as depicted in the Kernel Density surfaces which show the highest concentrations of both wealth and poverty to be in Tigray Region. 
GIS applications allow the calculation of statistical significance tests for the Kernel Density distributions shown in Figures $3 b$ and $3 c$ but require a minimum of 60 point locations. However, since we do not have 60 locations fitting the majority poor or majority rich criteria, we are not able to conduct a Kernel Density statistical test of significance. Typically, however, the darkest blue shade such as is found around Mekele - Tigray's capital - and darkest red shade in the countryside north and northwest of Mekele represent statistically significant concentrations of point locations sharing a given attribute. The attribute they share in this case is that of being a majority poor or a majority rich cluster. Overall, the population of the Amhara Region is not only richer when measured on the basis of DHS' wealth index, but appears to be more egalitarian with minimal geographic concentrations of either wealth or poverty. This is also evident in the finding that only $27 \%$ of the sample population in Amhara Region lived in clusters where households in the lowest and highest wealth quintiles constituted a majority of the sample population. Conversely, $41 \%$ of the sample population in Tigray Region lived in clusters where households in the lowest and highest wealth quintiles constituted a majority of the sample population. The large poverty cluster in the countryside north and northwest of Mekele could be explained in part by the lingering effects of the 1998-2000 war with Eritrea. In other words, the rhetoric of TPLF's exploits including its total dominance of Ethiopian society, economy, and power over the last 27 years, misses the enormous cost in livelihoods that the status quo of "no war no peace" (Woldemariam, M. 2018) brought on the populations living in Weredas and Kebels along the TigrayEritrea border prominently represented by the yellow/orange/red raster (Figure 3c).

\section{Discussion and Conclusion}

The results of our analyses do not support our working hypothesis of no difference in the economic status of the populations of Amhara and Tigray regions. Both the percentages and mean scores for radio, mobile phone, refrigerator, ownership, and access to electricity are higher in Tigray $(\mathrm{p}<0.001)$ than in Amhara Region. However, scores based on DHS' wealth index are lower in Tigray (Table 2 ) and statistically significant $(\mathrm{p}<0.001)$. The wealth index was calculated by using easy-to-collect data on ownership of certain assets, including television and bicycles; materials used for housing construction; and access to clean water and sanitation facilities (Rutstein and Johnson, 2004). Since DHS' wealth index is a composite of many important variables, and a far more comprehensive measure of a household's living standard, the finding of a lower score for Tigray (Table 2) is significant. It shows Tigray Region to be poorer than Amhara at the general population (not individual) levels, even as national and international sources report enormous wealth held by affluent Tigreans (Igunza, 2018). This lends credibility to the suspicion that the alleged misdirection of resources did not improve the living standards of ordinary Tigreans, the majority of whom lead agrarian lives in the rural countryside. In reporting this result, we are mindful of potential errors resulting from insufficiency of the chosen variables. Inability to conduct a test of significance for the Kernel Density surfaces shown in Figure $3 b$ and $3 c$ is also a limitation. We believe, however, that our results comport well with real life experiences of Tigray's population, the majority of whom earn a living working the land and struggling to get ahead just like their compatriots in other regions. We also believe that the results of this study have general applicability in similarly impacted developing counties where resources are misallocated with the pretext of helping the general population in the birth places of those in positions of power but end up enriching politically well-connected individuals. In addition, it appears that the best remedy to address real and perceived resource misdirection anywhere in the world is the institution of transparent democratic processes guaranteeing full representation of all stakeholders representing the entire geographic extent of a country, not just the parts the ruling elites come from.

It is hoped that lessons from this study can have a moderating impact on activists and politicians on a spectrum of ethnic politics locally and elsewhere in Africa still seeking ethnic homelands with leaderships roles reserved for "natives", to the exclusion of perceived outsiders and/or their descendants. In Ethiopia itself, the proliferation of newly organized parties and fronts representing major ethnic groups, including the Oromo, Amhara, Somali, Sidama, Tigray, Afar, Kimant, Argoba, Agew, etc. may be viewed as a new dawn in the exercise of democratic rights and freedoms, the declared goal of which include bringing prosperity to their respective areas of domicile. However, this can only succeed under a national agenda that is inclusive of all of the country's regions and peoples including the regions and peoples these fronts and parties do not represent. More importantly, the populations represented by these parties and fronts should be mindful of TPLF's near half-century experiment which did not bring prosperity to the people of Tigray. The lesson from this study appears to point to the virtues of harnessing the powers of a unified national quest for prosperity for all peoples, and to the fruitlessness of pursuing economic interests along ethnic lines or administrative boundaries.

In sum, the alleged misdirection of public goods to Tigray Region may have constituted a significance loss to the county as a whole, but seems unlikely to have benefitted the general population of Tigray. It appears that all but item \#2 of the four possibilities laid out in our problem statement have taken place in Tigray Region and in the rest 
of the country. The four possibilities we laid out were that: 1) individuals or groups in Tigray Region benefited while the population osaw no gain 2) the general public in Tigray benefited while the population in all of the nonfavored regions of Ethiopia saw no gain 3) the general public in Tigray and the rest of Ethiopia failed to see change in their economic standing as ill-intentioned program implementations resulted in significant national waste leading to mass anger and violence 4) liquid national assets combined with international aid dollars were targeted for misdirection by individuals away from Tigray Region and the rest of Ethiopia for safe keeping in international banks and for investment abroad. Quoting an Ethiopian macroeconomist and consultant named Eyob Tesfaye, a long-established Ethiopian news outlet recently reported the siphoning off of USD\$36 billion which is alleged to have left Ethiopia in the last two and a half decades (www.borkena.com).

In conclusion, we believe that this paper has added to the literature on redistributive politics which it viewed as a negative force in Ethiopian society and economy with oversized benefits to politicians purporting to help their region of birth while the alleged beneficiary populations struggled to get ahead despite decades of misdirected funds. Future research exploring the various mechanisms by which political institutions and state control in African and the rest of the developing world exercise ethnic or regional favoritism, could lead to more insightful findings and point us towards possible policy interventions. These interventions may help curb the enrichment of individuals while resources are being diverted in the name of a favored population they were alleged to be serving.

\section{References}

Aalen, L. (2016). Ethnic Federalism in a Dominant Party State: The Ethiopian Experience 1991-2000, Chr. Michelsen Institute Development Studies and Human Rights, Report R, 2002, 2. Retrieved from https://www.cmi.no/publications/769-ethnic-federalism-in-a-dominant-party-state

Abdullahi, M. A. (1998). Article 39 of the Ethiopian Constitution on Secession and Self-determination: A Panacea to the Nationality Question in Africa? Verfassung und Recht in Übersee / Law and Politics in Africa, Asia and Latin America, 31(4) (4. Quartal 1998), 440-455

Argaw, B. A. (2017). Regional inequality of economic outcomes and opportunities in Ethiopia A tale of two periods, WIDER Working Paper 2017/118, United Nations University, UNI-WIDER. Retrieved from https://www.wider.unu.edu/sites/default/files/wp2017-118.pdf

Asher, S., \& Paul, N. (2017). Politics and Local Economic Growth: Evidence from India. Applied Economics, 9(1), 229-73. Retrieved from https://www.aeaweb.org/articles?id=10.1257/app.20150512

Axel Dreher Stephan Klasen James Raymond Vreeland Eric Werkerces, The Costs of Favoritism: Is PoliticallyDriven Aid Less Effective? IZA Discussion Paper Series, DP No. 4820 March 2010, Retrieved from https://pdfs.semanticscholar.org/f294/3458fb231cdea1995d83239644fa860305bd.pdf

Aynalem, A. (2017). Retrieved from http://www.ethiodemographyandhealth.org/Ethiopian_ Demography_AynalemAdugna_November2017.pdf

Carter Center Final Report. (2009). Observing the 2005 Ethiopia National Elections, Retrieved from http://www.cartercenter.org

Central Statistical Authority and ORC Macro. (2001). Ethiopia Demographic and Health Survey 2000, Addis Ababa, Ethiopia and Calverton, Maryland, USA. Retrieved from https://dhsprogram.com/pubs/pdf/FR118/FR118.pdf

Central Statistical Authority and ORC Macro. (2006). Ethiopia Demographic and Health Survey 2005, Addis Ababa, Ethiopia and Calverton, Maryland, USA, Retrieved from https://www.dhsprogram.com/pubs/pdf/fr179/fr179\%5B23june2011\%5D.pdf

Central Statistical Authority and ORC Macro. (2011). Ethiopia Demographic and Health Survey 2010, Addis Ababa, Ethiopia and Calverton, Maryland, USA, https://dhsprogram.com/pubs/pdf/fr255/fr255.pdf

Central Statistical Authority and ORC Macro. (2011). Ethiopia Demographic and Health Survey 2016, Addis Ababa, Ethiopia and Calverton, Maryland, USA. Retrieved from https://dhsprogram.com/pubs/pdf/FR328/FR328.pdf

Daniel, W. G. (2008). A Geocoding Best Practices Guide, University of Southern California GIS Research Laboratory. Retrieved from https://20tqtx36s1la18rvn82wcmpn-wpengine.netdna-ssl.com/wpcontent/uploads/2016/11/Geocoding_Best_Practices.pdf

Davide, L., \& Andres, R. P. (2015). Distributive politics and regional development: assessing the territorial distribution of Turkey's public investment. Journal of Development Studies. ISSN 0022-0388, Retrieved from 
http://eprints.lse.ac.uk/63203/1/_lse.ac.uk_storage_LIBRARY_Secondary_libfile_shared_repository_Cont ent_Rodr\%C4\%B1guez.pdf

Dreher, A., Klasen, S., Vreeland, J. R., \& Werkerces, E. (2010). The Costs of Favoritism: Is Politically-Driven Aid Less Effective? IZA Discussion Paper Series, DP No.

Eric Cai. (2013). Retrieved from https://chemicalstatistician.wordpress.com/2013/06/09/exploratory-dataanalysis-kernel-density-estimation-in-r-on-ozone-pollution-data-in-new-york-and-ozonopolis/

ESAT. (2018). Ethiopia lost \$36B in illicit financial flows, Ethiopian Satellite Television and Radio. Retrieved from https:/ethsat.com/2018/12/ethiopia-lost-36b-in-illicit-financial-flows/

Federal Democratic Republic of Ethiopia (FDRE). (1995). Central Statistical Authority (CSA), The 1994 Population and Housing Census of Ethiopia, Results for the Amhara Region, Volume II, Analytical Report

Federal Democratic Republic of Ethiopia (FDRE). (1995). Central Statistical Authority (CSA), The 1994 Population and Housing Census of Ethiopia, Results for Tigray Region, Volume II, Analytical Report

Golden, M., \& Min, B. (2013). Distributive Politics Around the World. Annu. Rev. Polit. Sci., 16, 73-99. Retrieved from https://pdfs.semanticscholar.org/673a/9a8bb0ed135d4a0d8db6292e6d79e4fd9db0.pdf

Hazelkorn, E., \& Gibson, A. (2017). Centre for Global Higher Education, Public goods and public policy: what is public good, and who and what decides? Working Paper Series no. 18 May 2017. Retrieved from https://www.researchcghe.org/perch/resources/publications/wp18.pdf

Hodler, R., \& Raschky, P. A. (2014). Regional Favoritism. The Quarterly Journal of Economics, 129(2), 995-1033. Retrieved from http://www.agi.or.jp/workingpapers/WP2017-16.pdf

Igunza, E. (2018). BBC Africa/Ethiopia. Ethiopia's PM Abiy Ahmed takes on the military. Retrieved from https://www.bbc.com/news/world-africa-46221240

Ilorah, R. (2009). Ethnic bias, favouritism and development in Africa, Journal Development Southern Africa, 26, 2009(5). Retrieved from https://www.tandfonline.com/doi/full/10.1080/03768350903303209

Kramon, E., \& Posner, D. N. (2013). Who Benefits from Distributive Politics? How the Outcome One Studies Determines the Answer One Gets. American Political Science Association, 11(2). Retrieved from https://www.cambridge.org/core/journals/perspectives-on-politics/article/who-benefits-from-distributivepolitics-how-the-outcome-one-studies-affects-the-answer-onegets/7920F6966363B66413250514119EF2BF

Luca, D. G., Hodler, R., Raschky, P. A., \& Valsecchi, M. (2015). Ethnic Favoritism: An Axiom of Politics? Cesifo Working Paper No. 5209 CATEGORY 2: Public Choice February 2015. Retrieved from https://lir.gu.se/digitalAssets/1516/1516251_ethnic_favoritism_draft_150206rh.pdf

McCracken, M. J. (2004). Abusing Self-Determination and Democracy: How the TPLF Is Looting Ethiopia. Case Western Reserve Journal of International Law. Volume 36, Issue 1. School of Law, Case Western University. Retrieved from https://scholarlycommons.law.case.edu/cgi/viewcontent.cgi?article=1390\&context=jil

Michael Woldemariam. (2018). "No war, no peace" in a region in flux: crisis, escalation, and possibility in the Eritrea-Ethiopia rivalry. Journal of Eastern African Studies, 12(3). Retrieved from https://www.tandfonline.com/doi/abs/10.1080/17531055.2018.1483865? journalCode=rjea20

Rainer, R. F. I. (2009). Does the Leader's Ethnicity Matter? Ethnic Favoritism, Education and Health in SubSaharan Africa. Retrieved from http://cega.berkeley.edu/assets/miscellaneous_files/wgape/18_Rainer.pdf

Reid, R. (2003). Old problems in new conflicts: some observations on Eritrea and its relations with Tigray, from liberation struggle to inter-state war., Africa., 73(3), 369-401. Retrieved from http://dro.dur.ac.uk/397/1/397.pdf?DDD17+dac0hsg+dhi0ts

Rutstein, S. O., \& Johnson, K. (2004). The DHS Wealth Index, DHS Comparative Reports No. 6, ORC Macro, Calverton, MD, USA. Retrieved from https://dhsprogram.com/pubs/pdf/cr6/cr6.pdf

Sam, A., \& Novosad, P. (2017). Politics and Local Economic Growth: Evidence from India. Applied Economics, 9(1), 229-73. Retrieved from http://www.dartmouth.edu/ novosad/asher-novosad-politicians.pdf

Sarah, V., \& Mesfin, G. (2011). Rethinking business and politics in Ethiopia: The role of EFFORT, the Endowment Fund for the Rehabilitation of Tigray, Africa Power and Politics, Research Report 02. Retrieved from http://www.institutions-africa.org/filestream/20110822-appp-rr02-rethinking-business-politics-in-ethiopiaby-sarah-vaughan-mesfin-gebremichael-august-2011 
SAS Institute Inc. (2008). SAS/STAT 9.2 User's Guide The NPAR1WAY Procedure, Retrieved from $\mathrm{http}$ ://support.sas.com/documentation/cdl/en/statugnpar1way/61813/PDF/default/statugnpar1way.pdf

Selassie, G. A. (1992). Ethiopia: Problems and Prospects for Democracy. William and Mary Bill of Rights Journal, 1(2), Article 4. Retrieved from https://scholarship.law.wm.edu/wmborj/voll/iss2/4/

Tadesse, M. (2003). TPLF: Reform or Decline? Review of African Political Economy, 30(97). Retrieved from https://www.tandfonline.com/doi/abs/10.1080/03056244.2003.9659773

Tigray Housing Development Agency. (2017). Housing assessment report. Mekelle, Tigray. Unpublished report.

Timár, G., \& Molnár, G. (2013). Map grids and datums. Eötvös Lóránd University. http://elte.prompt.hu/sites/default/files/tananyagok/MapGridsAndDatums/book.pdf

Uliah, O. (2017). Analysis: Inside the Controversial EFFORT, Addis Standard, January 16, 2017. Retrieved from http://addisstandard.com/analysis-inside-controversial-effort/

UNDP. (2017). UNDP'S Strategy for Inclusive and Sustainable Growth. United Nations Development Program. Retrieved from http://www.undp.org/content/dam/undp/library/Poverty\%20Reduction/UNDPs\%20Inclusive\%20and\%20Su stainable\%20Growth-final.pdf

Vaughan, S., \& Gebremichael, M. (2011). Rethinking Business and Politics in Ethiopia: The role of EFFORT, the Endowment Fund for the Rehabilitation of Tigray, Africa, Power, and Politics, Research Report, 02. Retrieved from http://www.institutions-africa.org/filestream/20110822-appp-rr02-rethinking-business-politics-inethiopia-by-sarah-vaughan-mesfin-gebremichael-august-2011

Veen, E. V. (2016). Perpetuating power. Ethiopia's political settlement and the organization of security. Clingendael, Netherland's Institute of International Relations. CRU Report. Retrieved from https://www.clingendael.org/sites/default/files/pdfs/power_politics_and_security_in_ethiopia_2.pdf

Vu, T. M., \& Yamada, H. (2017). Firms and Regional Favoritism, Institute for Economic Studies, Keio University Keio-IES Discussion Paper Series DP No. 2017-025. Retrieved from http://www.agi.or.jp/workingpapers/WP2017-16.pdf

WFP-Ethiopia. (2009). Vulnerability Assessment and Mapping (VAM), Food Security and Vulnerability in Selected Towns of Tigray Region, Ethiopia. Addis Ababa, Ethiopia September 2009. Retrieved from https://documents.wfp.org/stellent/groups/public/documents/ena/wfp221389.pdf

Woldemariam Michael (2018). "No war, no peace" in a region in flux: crisis, escalation, and possibility in the Eritrea-Ethiopia rivalry. Journal of Eastern African Studies, 12(3). Retrieved from https://www.tandfonline.com/doi/abs/10.1080/17531055.2018.1483865? journalCode=rjea20

World Bank. (2009). Toward the Competitive Frontier: Strategies for Improving Ethiopia's Investment Climate, Finance and Private Sector Development Africa Region,

Yilmaz, S., \& Venugopal, V. (2008,). Local Government Discretion and Accountability in Ethiopia, International Studies Program, Working Paper 08-38, December 2008. Retrieved from https://siteresources.worldbank.org/EXTSOCIALDEVELOPMENT/Resources/Ethiopia.pdf

\section{Copyrights}

Copyright for this article is retained by the author(s), with first publication rights granted to the journal.

This is an open-access article distributed under the terms and conditions of the Creative Commons Attribution license (http://creativecommons.org/licenses/by/4.0/). 